University of Wisconsin Milwaukee

UWM Digital Commons

$2-28-2020$

\title{
Magnetic Mineral Populations in Lower Oceanic Crustal Gabbros (Atlantis Bank, SW Indian Ridge): Implications for Marine Magnetic Anomalies
}

Julie A. Bowles

A. Morris

M. A. Tivey

Ioan Lascu

Follow this and additional works at: https://dc.uwm.edu/geosci_facart

This Article is brought to you for free and open access by UWM Digital Commons. It has been accepted for inclusion in Geosciences Faculty Articles by an authorized administrator of UWM Digital Commons. For more information, please contact open-access@uwm.edu. 


\section{Geochemistry, Geophysics, Geosystems}

\author{
RESEARCH ARTICLE \\ 10.1029/2019GC008847 \\ Key Points: \\ - Magnetite in Atlantis Bank gabbros \\ is present as single-domain \\ inclusions in silicate minerals and as \\ intergrowths in coarse oxides \\ - Fine-scale lamellar intergrowths in \\ the coarse oxides give rise to \\ pseudo-single-domain-like behavior \\ and likely dominates near-bottom \\ anomalies \\ - Thermomagnetic data are consistent \\ with high-temperature \\ hydrothermal alteration in the \\ uppermost 200-500 m
}

Supporting Information:

- Supporting Information S1

- Table S1

Correspondence to:

J. A. Bowles,

bowlesj@uwm.edu

Citation:

Bowles, J. A., Morris, A., Tivey, M. A., \& Lascu, I. (2020). Magnetic mineral populations in lower oceanic crustal gabbros (Atlantis Bank, SW Indian Ridge): Implications for marine magnetic anomalies. Geochemistry, Geophysics, Geosystems, 21, e2019GC008847. https://doi.org/ 10.1029/2019GC008847

Received 3 DEC 2019 Accepted 27 FEB 2020 Accepted article online 28 FEB 2020

(C)2020. American Geophysical Union. All Rights Reserved.

\section{Magnetic Mineral Populations in Lower Oceanic Crustal Gabbros (Atlantis Bank, SW Indian Ridge): Implications for Marine Magnetic Anomalies}

\author{
J. A. Bowles ${ }^{1}$ iD, A. Morris ${ }^{2}$ iD, M. A. Tivey ${ }^{3}$ iD, and I. Lascu 4 iD \\ ${ }^{1}$ Department of Geosciences, University of Wisconsin-Milwaukee, Milwaukee, WI, USA, ${ }^{2}$ School of Geography, Earth and \\ Environmental Sciences, University of Plymouth, Plymouth, UK, ${ }^{3}$ Department of Geology and Geophysics, Woods Hole \\ Oceanographic Institution, Woods Hole, MA, USA, ${ }^{4}$ Department of Mineral Sciences, National Museum of Natural \\ History, Smithsonian Institution, Washington, DC, USA
}

\begin{abstract}
To learn more about magnetic properties of the lower ocean crust and its contributions to marine magnetic anomalies, gabbro samples were collected from International Ocean Discovery Program Hole U1473A at Atlantis Bank on the Southwest Indian Ridge. Detailed magnetic property work links certain magnetic behaviors and domain states to specific magnetic mineral populations. Measurements on whole rocks and mineral separates included magnetic hysteresis, first-order reversal curves,

low-temperature remanence measurements, thermomagnetic analysis, and magnetic force microscopy. Characteristics of the thermomagnetic data indicate that the upper $\sim 500 \mathrm{~m}$ of the hole has undergone hydrothermal alteration. The thermomagnetic and natural remanent magnetization data are consistent with earlier observations from Hole 735B that show remanence arises from low-Ti magnetite and that natural remanent magnetizations are up to $25 \mathrm{~A} \mathrm{~m}^{-1}$ in evolved Fe-Ti oxide gabbros, but are mostly $<1 \mathrm{~A} \mathrm{~m}^{-1}$. Magnetite is present in at least three forms. Primary magnetite is associated with coarse-grained oxides that are more frequent in the upper part of the hole. This magnetic population is linked to dominantly "pseudo-single-domain" behavior that arises from fine-scale lamellar intergrowths within the large oxides. Deeper in the hole the magnetic signal is more commonly dominated by an interacting single-domain assemblage most likely found along crystal discontinuities in olivine and/or pyroxene. A third contribution is from noninteracting single-domain inclusions within plagioclase. Because the concentration of the highly magnetic, oxide-rich gabbros is greatest toward the surface, the signal from coarse oxides will likely dominate the near-bottom magnetic anomaly signal at Atlantis Bank.
\end{abstract}

Plain Language Summary Critical evidence documenting Earth's evolution has been provided by measuring the magnetic field generated by a magnetized ocean crust. Most of this field comes from the uppermost crust produced by seafloor volcanic eruptions. However, sometimes important contributions come from the lower crust that is not commonly exposed on the seafloor. To better understand these lower crustal contributions, rock samples were collected via ocean drilling at Atlantis Bank in the Indian Ocean. Previous magnetic work on this type of rock has mostly been limited to measurements that provide an average of all magnetic minerals present. In this study, we perform more detailed analyses and are able to link certain magnetic behaviors with specific populations of the magnetic mineral magnetite. In one form, magnetite is present in relatively large (tens of microns) oxide minerals with fine-scale compositional variations. Magnetite is also present as tiny particles enclosed within other minerals (plagioclase and pyroxene and/or olivine). Because rock layers containing the large oxides are relatively close to the seafloor at Atlantis Bank, and because they contain a large quantity of magnetite, they will contribute most strongly to any magnetic field measurements made close to the seafloor.

\section{Introduction/Background}

Sea-surface marine magnetic anomalies have provided critical evidence in the development of plate tectonic theory (Heirtzler et al., 1968; Vine \& Matthews, 1963), allowing for the reconstruction of mid-ocean ridge plate boundaries through time, and proving important in the development and refinement of the Geomagnetic Polarity Time Scale (Cande \& Kent, 1995; Pitman \& Heirtzler, 1966). More recently, near-bottom magnetic data have provided more detailed information on geomagnetic field behavior (e.g., 
Bowers et al., 2001; Gee et al., 2000; Granot et al., 2012; Sager et al., 1998; Tivey et al., 2006; Tominaga et al., 2008) and local tectonic and hydrothermal processes (e.g., Caratori Tontini et al., 2016; Tivey et al., 2003; Tivey \& Johnson, 2002). A complete interpretation of these data requires understanding of the source layers, magnetic mineralogy, and stability of magnetization. When present, an extrusive layer may dominate the signal (Gee \& Kent, 2007), but contributions from the lower crust remain important, especially when little to no extrusive layer exists (e.g., Dick et al., 1991; Schulz et al., 1988; Tivey \& Tucholke, 1998). Even when the extrusive crust is present, an understanding of lower crustal magnetization is often required. For example, paleomagnetic poles can be determined by quantifying the phase shift of the sea-surface anomaly (Schouten \& Cande, 1976). This technique assumes that polarity boundaries within the crust are vertical, an assumption that is almost certainly violated by sloping boundaries in the extrusive crust due to accretionary processes (Macdonald et al., 1983; Schouten \& Denham, 1979; Tivey et al., 1998). A greater effect within the lower crust may arise from inferred sloping boundaries due to cooling isotherms (Arkani-Hamed, 1990; Cande \& Kent, 1976; Dyment et al., 1994; Gee \& Kent, 2007).

Characterizing the magnetic properties of the lower crust is therefore important, and existing data from the lower oceanic crust are still limited to mostly bulk magnetic property observations. Here we present new rock magnetic data on lower crustal samples from International Ocean Discovery Program Hole U1473A that give a more detailed picture of links between the documented magnetic mineral populations and their specific magnetic behaviors and properties.

\subsection{Site Description}

International Ocean Discovery Program Expedition 360 recovered lower crustal samples from the Atlantis Bank oceanic core complex on the Southwest Indian Ridge (MacLeod et al., 2017b). Located $100 \mathrm{~km}$ south of the Southwest Indian Ridge spreading axis and $\sim 10 \mathrm{~km}$ east of the Atlantis II Transform $\left(32^{\circ} 42.36^{\prime} \mathrm{S}, 57^{\circ}\right.$ $\left.16.69^{\prime} \mathrm{E}\right)$, the upper crust here has been removed via long-lived detachment faulting, exposing the gabbroic lower crust at the seafloor (Dick et al., 2000; Natland \& Dick, 2001; Dick, Kvassnes, et al., 2019, Dick, MacLeod, et al., 2019). Sea-surface and near-bottom marine magnetic anomalies are continuous across Atlantis Bank (Allerton \& Tivey, 2001; Dick et al., 1991). Combined with remanence data from Ocean Drilling Program Hole 735B and several seabed drill sites, these anomalies have been used to model the dip of the magnetic isochron away from the ridge axis (Allerton \& Tivey, 2001). Hole U1473A was drilled to $809-\mathrm{m}$ core composite depth below seafloor (CCSF) and is located $2.2 \mathrm{~km}$ north-northeast of Hole $735 \mathrm{~B}$ (1,508 $\mathrm{m}$ deep) and $1.4 \mathrm{~km}$ north of Hole $1105 \mathrm{~A}$ (148 $\mathrm{m}$ deep). It was drilled into the $12 \mathrm{Myr}$, reversely magnetized crust of Chron C5r.3r (MacLeod et al., 2017b).

The gabbroic sequence at Atlantis Bank is interpreted to represent a period of robust magmatism. The gabbros are dominantly evolved adcumulates, residue of a highly fractionated mid-ocean ridge basalt (Dick, Kvassnes, et al., 2019). At U1473A, the recovered gabbros are mostly olivine gabbro, with lesser amounts of gabbro and oxide-bearing gabbros (Figure 1). The most oxide-rich gabbros are thought to represent an evolved interstitial melt compacted out of olivine gabbro cumulates (MacLeod et al., 2017b). In addition to the gabbros, approximately $1.5 \%$ of the recovered section is felsic veins, possibly representing the final stages of melt fractionation.

Based on shipboard hand-sample and petrographic observations, the gabbros were placed in three different categories for magnetic purposes (MacLeod et al., 2017a): (1) no visible oxides (gabbros and olivine gabbros), (2) $<5 \%$ oxides (disseminated oxide gabbros, oxide-bearing gabbros, and oxide-bearing olivine gabbros), and (3) $>5 \%$ oxides (oxide gabbros and olivine oxide gabbros). While groups 2 and 3 have significant concentrations of visible coarse, primary magmatic oxides, many group 1 samples also likely contain primary oxides that were not easily observed in hand sample.

A 600-m-thick crystal-plastic shear zone at the top of Hole U1473A is consistent with an active detachment fault during magmatic accretion of the lower crust. Extensive recrystallization is associated with this deformation, and the entire recovered section shows evidence of pervasive but locally variable static hydrothermal alteration (MacLeod et al., 2017a).

Challenging coring conditions were encountered at $\sim 410 \mathrm{~m} \mathrm{CCSF}$, which corresponded to the top of an 100-m-thick fault zone, the lowermost $37 \mathrm{~m}$ of which were drilled without coring (Figure 1). Three roller cones were lost from one bit at $410 \mathrm{~m} \mathrm{CCSF}$, and attempts to retrieve them with a strong magnet may 


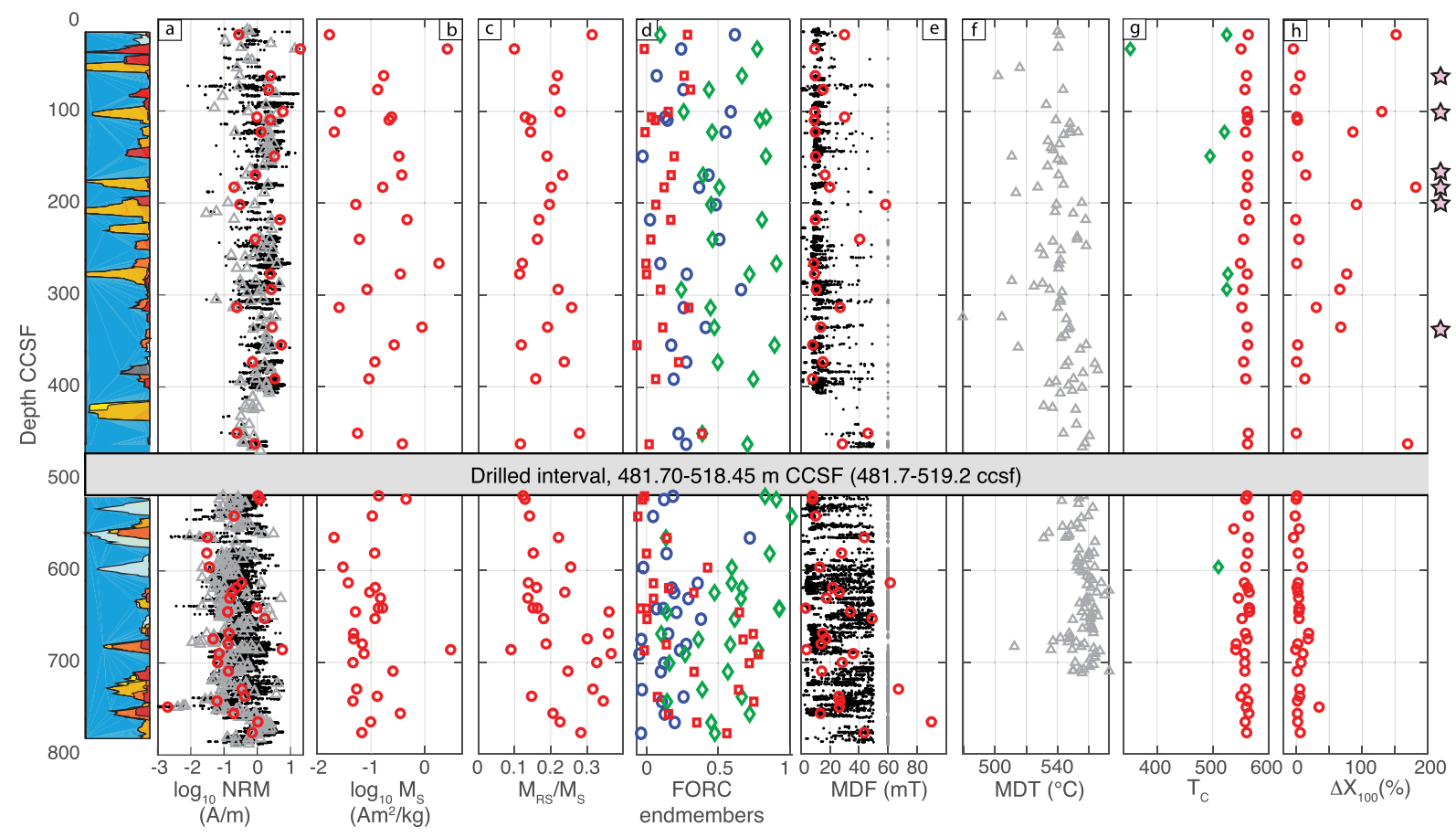

Figure 1. Downhole variations in magnetic properties. (a) NRM. (b) Saturation magnetization. (c) Saturation remanent magnetization ( $\mathrm{M}_{\mathrm{RS}}$ )/saturation magnetization $\left(\mathrm{M}_{\mathrm{S}}\right)$. (d) Relative abundance of FORC endmembers: blue circles = EM1 (noninteracting $\mathrm{SD}$ ), red squares = EM2 (interacting SD), green diamonds = EM3 + EM4 (PSD). (e) Median destructive field (MDF). (f) Median destructive temperature (MDT). (g) Curie temperature: dominant $\mathrm{T}_{\mathrm{C}}$ in red circles, secondary $\mathrm{T}_{\mathrm{C}}$ in green diamonds. (h) Percent change in susceptibility after heating to $700{ }^{\circ} \mathrm{C}$. Pink stars indicate samples where "hump" was observed in thermomagnetic data. MDF for pass-through data is limited to $\leq 60 \mathrm{mT}$, the maximum demagnetization step. MDT was calculated using only fraction of remanence present after heating to $150^{\circ} \mathrm{C}$; all samples were subjected to low-temperature demagnetization in liquid $\mathrm{N}$ prior to thermal demagnetization. Small black dots $=$ shipboard pass-through data. Gray triangles = shipboard discrete samples. Red/blue/green symbols = rock magnetic samples (this study). All shipboard data are from MacLeod et al. (2017a). Dominant lithology of the recovered core indicated in panel at the left (10-m running average); blues are dominantly gabbros and olivine gabbros, oranges and yellows are disseminated oxide and oxide-bearing gabbros, and reds are oxide gabbros (from MacLeod et al., 2017a).

have re-magnetized the bottom hole assembly of the drill string and/or the drill pipe. This depth corresponds to a change in the nature of the low-coercivity drilling overprint and may have some influence on the natural remanent magnetization characteristics (MacLeod et al., 2017a).

\section{Lower Crustal Magnetization}

Magnetic property data for oceanic gabbros come predominantly from ocean drilling in a handful of locations: the oceanic core complexes at Atlantis Bank on the Southwest Indian Ridge (Kikawa \& Pariso, 1991; Pariso \& Johnson, 1993; Rao \& Krishna, 2002; Shipboard Scientific Party, 1989, 1999) and Atlantis Massif on the Mid-Atlantic Ridge (MAR; Expedition 304/305 Scientists, 2006; Morris et al., 2009; Zhao \& Tominaga, 2009), two series of holes on the MAR near the Kane (Gee et al., 1997; Gee \& Meurer, 2002) and the $15^{\circ} 20^{\prime} \mathrm{N}$ fracture zones (Garcés \& Gee, 2007; Kelemen et al., 2004), and in the Hess Deep rift valley on the Cocos-Nazca spreading center (Pariso et al., 1996). In addition to paleomagnetic directional behavior, most of these studies report only bulk rock magnetic properties such as natural remanent magnetization $(\mathrm{NRM})$, median destructive field (MDF), median destructive temperature, and/or Curie temperature $\left(T_{c}\right)$.

On average, the NRM of gabbros is less than that of basalts or dikes, although there is considerable variability in both populations. Gee and Kent (2007) summarize NRM data (their Table 2) and estimate an average of $\sim 1 \mathrm{~A} \mathrm{~m}^{-1}$ as typical of oceanic gabbros, compared to $\sim 5 \mathrm{~A} \mathrm{~m}^{-1}$ for basalts. With the exception of some Fe-Ti oxide-rich gabbros, the dominant magnetic phase is low-Ti magnetite.

This magnetite is present in at least three forms. Most gabbros appear to have magnetite as fine-grained, crystallographically controlled inclusions in silicate grains, including plagioclase, pyroxene, and olivine (Davis, 1981; Gee \& Meurer, 2002; Natland, 2002; Usui, 2013). Magnetite is also commonly found as aggregates along 
fractures in olivine and pyroxene associated with alteration (Expedition 304/305 Scientists, 2006; Natland, 2002; Pariso \& Johnson, 1993; Usui, 2013). Coarse-grained, discrete, primary magnetite is often coarsely intergrown with ilmenite and is most commonly found in more evolved Fe-Ti oxide gabbros (Expedition 304/305 Scientists, 2006; Natland, 2002; Pariso \& Johnson, 1993).

\subsection{Lower Crustal Magnetization at Atlantis Bank}

All three of these types of magnetite are found in the Atlantis Bank gabbros. As observed at Hole 735B (e.g., Kikawa \& Pariso, 1991; Pariso \& Johnson, 1993) and 1105A (Rao \& Krishna, 2002), the top of Hole U1473A has a higher proportion of oxide-rich gabbros that (on average) are characterized by lower coercivities and often slightly lower unblocking temperatures (MacLeod et al., 2017a). At Hole U1473A, there is a correlation between visible oxide abundance and increasing NRM and susceptibility. Of the three gabbro lithology groups defined above for magnetic purposes, group 1 (no visible oxides) has a geometric mean NRM intensity of $0.45 \mathrm{~A} \mathrm{~m}^{-1}$ (range $0.49 \mathrm{~mA} \mathrm{~m}^{-1}$ to $9.0 \mathrm{~A} \mathrm{~m}^{-1}$ ), while group 3 (>5\% oxides) has a mean of $2.11 \mathrm{~A} \mathrm{~m}^{-1}$ (range $13.3 \mathrm{~mA} \mathrm{~m}^{-1}$ to $19.7 \mathrm{~A} \mathrm{~m}^{-1}$ ). There is a clear trend in the average NRM intensity with shipboard estimates of oxide abundance, but there is a wide range within each group and they overlap considerably. This is likely due to core heterogeneity and the necessarily approximate nature of the shipboard oxide abundance estimates and lithologic unit assignments. There may also be some variation in the fraction of oxides that are magnetic.

Based on Expedition 360 shipboard observations (MacLeod et al., 2017a) and on previous work at Hole 735B (Natland, 2002), the oxide-rich gabbros are dominated by primary, magmatic, coarse-grained magnetite. Average coercivity increases in the lower part of the hole, and this is accompanied by a slight increase in unblocking temperature and a decrease in average intensity (Figures 1a, 1e, and 1f; MacLeod et al., 2017a). This suggests that the magnetic carriers in the less magnetic rocks may be largely confined to silicate-hosted, exsolved magnetite and/or magnetite associated with olivine or pyroxene alteration (Kikawa \& Pariso, 1991; MacLeod et al., 2017a; Natland, 2002; Pariso \& Johnson, 1993).

\section{Methods}

Fifty-three unoriented samples for rock magnetic analysis were taken from the working-half sections of the cores and were subdivided into three splits for (1) alternating field (AF) demagnetization of NRM; (2) susceptibility as a function of temperature, $\chi(\mathrm{T})$; and (3) other rock magnetic work. At the University of Wisconsin-Milwaukee Paleomagnetic Laboratory, all remanence measurements were made on a $2 \mathrm{G}$ Enterprises 755SRMS Superconducting Rock Magnetometer, and NRM was AF demagnetized using an ASC D-2000 AF Demagnetizer. Sample orientation in the demagnetizer was reversed at each demagnetization step $(+x /+y /+z$ versus $-x /-y /-z)$ to detect any spurious ARM acquisition during demagnetization. To assess acquisition of a gyroremanent magnetization, nine samples were additionally subjected to a triple demagnetization scheme (Stephenson, 1993) starting at $30 \mathrm{mT}$, whereby the sample was measured after demagnetization along all three $x-y-z$ axes, then after demagnetization along the $y$ axis, and again after demagnetization along the $x$ axis.

$\chi(\mathrm{T})$ was measured under flowing Ar on crushed splits using a Kappabridge MFK1-FA susceptibility bridge with CS4 furnace attachment. Curie temperatures $\left(T_{c}\right)$ were estimated by finding the (negative) peak in the first derivative of $\chi(\mathrm{T})$ (Petrovský \& Kapička, 2006). Issues with the calibration of the temperature sensor lead an underreporting of most temperatures in the range of the magnetite $T_{c}$ by $\sim 10-13^{\circ} \mathrm{C}$. We do not adjust any temperatures reported here but discuss the implications for interpretation below.

Hysteresis loops, first-order reversal curves (FORCs), and low-temperature remanence measurements were conducted at the Institute for Rock Magnetism at the University of Minnesota. Hysteresis was measured in fields up to $1 \mathrm{~T}$ on a Princeton Measurements Corp., vibrating sample magnetometer. FORC data were collected every $2 \mathrm{mT}$ and were processed using FORCinel 3.07 (Harrison \& Feinberg, 2008) with the VARIFORC variable smoothing protocol (Egli, 2013). To quantify downhole variability in the magnetic components, we conducted a principal component analysis of the FORCs (Harrison et al., 2018; Lascu et al., 2015). Endmember selection was guided by a feasibility metrics algorithm, which defines an unmixing space in which endmembers (EMs) are physically realistic (Harrison et al., 2018). 
Low-temperature $(<300 \mathrm{~K}$ ) remanence data were collected on 19 of the samples using a Quantum Designs Magnetic Property Measurement System. A 2.5-T isothermal remanent magnetization was acquired at 300 $\mathrm{K}$. The sample was then cycled to $10 \mathrm{~K}$ and back to $300 \mathrm{~K}$. Samples were then field-cooled (FC) in a 2.5-T field to $10 \mathrm{~K}$ and remanence was measured on warming. Finally, samples were cooled in zero field (ZFC) and remanence was measured on warming.

To evaluate the contribution from silicate-hosted oxides, six samples were crushed, and plagioclase and pyroxene minerals were separated by hand. Hysteresis and FORC measurements were then repeated on aggregates of these mineral separates. Mineral identification was tested via powder X-ray diffraction (XRD) at University of Wisconsin-Milwaukee using a Bruker D8 Focus XRD system at room temperature $(\mathrm{Cu} \mathrm{K} \alpha$ radiation, $4 \mathrm{~s}$ per $0.01^{\circ} 2 \theta, 2-60^{\circ}$ range, Sol-X energy dispersive detector). This confirmed that the plagioclase separates were nearly pure, but that the pyroxene separate also contained significant amounts of olivine.

Finally, to assess the internal magnetic structure of the coarse magmatic oxides, three $\sim 1 \times 1$-cm-thick sections were prepared for magnetic force microscopy (MFM) by polishing, finishing with a colloidal silica polish. The work was carried out on an Asylum Research MFP3D, equipped with a heated stage. Sample surface topography (height) was collected in tapping mode, and the magnetic information (phase) was collected with the MFM tip at 50-nm elevation.

\section{Results}

\subsection{NRM and Demagnetization Behavior}

The NRM of the oxide gabbros can be in excess of $20 \mathrm{~A} \mathrm{~m}^{-1}$. However, the majority of the samples have NRMs $\leq \sim 1 \mathrm{~A} \mathrm{~m}^{-1}$, in agreement with the compilation of Gee and Kent (2007). The NRM and MDF values are in agreement with both the shipboard pass-through and discrete sample data (Figures 1a and 1e). Although there is considerable downhole variability, the general trend is of higher NRM and lower MDF above 400 $\mathrm{m}$ CCSF.

During AF demagnetization, approximately 35\% samples were characterized by an increase in remanence at treatments above about 40-60 mT and a direction that does not decay to origin of a vector endpoint diagram (Figure S1 in the supporting information). This behavior was mitigated when samples were subjected to the triple-demagnetization protocol and the three measurements were averaged (Figure S2). This is consistent with acquisition of a gyroremanent magnetization during AF demagnetization, typical of single-domain (SD) particles (Stephenson, 1993). This behavior is only observed at depths $>450 \mathrm{~m}$ CCSF, consistent with the downhole increase in coercivity.

\subsection{Hysteresis and FORC Data}

Standard hysteresis parameters are reported in Table S1 in the supporting information, including saturation magnetization $\left(M_{S}\right)$, saturation remanent magnetization $\left(M_{\mathrm{rs}}\right)$, coercivity $\left(B_{c}\right)$, and coercivity of remanence $\left(B_{\mathrm{cr}}\right)$. On a standard Day plot (Day et al., 1977) of $M_{\mathrm{rs}} / M_{S}$ versus $B_{\mathrm{cr}} / B_{c}$ (Figure 2), all specimens plot in the zones traditionally interpreted as near SD to pseudo-single domain (PSD). With one exception, samples with the most SD-like hysteresis parameters $\left(M_{\mathrm{rs}} / M_{S}>0.3\right)$ are found exclusively in the deepest parts of the hole (>640 m CCSF; Figure 1c). These also tend to be the samples with the lowest volumetric abundance of magnetic minerals (as reflected by $M_{S}$ ), while samples with higher $M_{S}$ are less SD-like (Figure 2).

FORC analysis provides a more nuanced assessment of the full range of magnetic populations and behaviors and suggests contributions from at least three magnetic components. A noninteracting SD component is evidenced by a narrow ridge along $B_{u}=0$, with coercivities in excess of $170 \mathrm{mT}$ (Figures $3 \mathrm{~b}$ and $3 \mathrm{e}$ ). A similar component is observed in the plagioclase separate (Figure 3e), as well as in plagioclase crystals from MAR gabbros (Usui, 2013). This component may therefore be due to magnetic inclusions in the plagioclase, but chains of SD particles observed in some of the coarse magmatic oxides (section 4.5 below) may also contribute.

A second component has peak coercivities around 10-40 mT, with increased vertical spread in the $B_{u}$ distribution, but with contours that close on both sides of the peak (Figures $3 \mathrm{c}$ and $3 \mathrm{f}$ ) suggesting a slightly interacting SD component. This component dominates the olivine/pyroxene separates (Figure 3f) and is very similar to that observed by Usui (2013) in olivine separates from MAR gabbros. It is also similar to an 

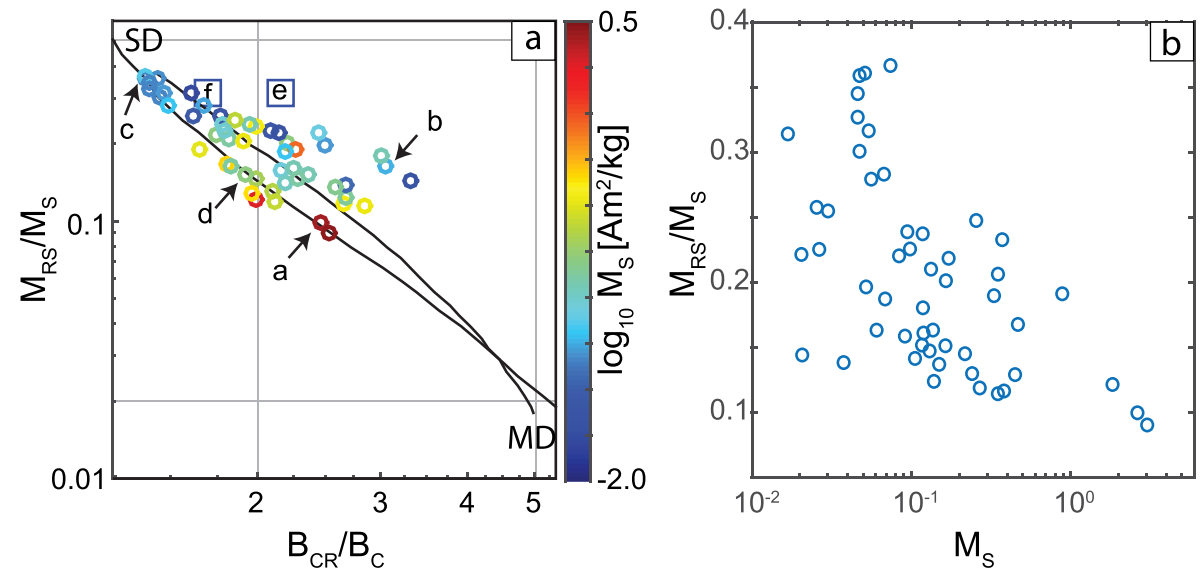

Figure 2. (a) Day plot (Day et al., 1977) showing hysteresis properties as a function of $\mathrm{M}_{\mathrm{S}}$. There is a trend toward more SD-like properties downhole, but in general samples with a greater abundance of magnetic minerals (reflected in higher $\mathrm{M}_{\mathrm{S}}$ ) are also less SD-like. SD-MD mixing curves for magnetite from Dunlop (2002). Letters refer to FORC diagram panels in Figure 3. All data are from whole rocks, with the exception of blue squares e and $\mathrm{f}$ which are from mineral separates. (b) $\mathrm{M}_{\mathrm{RS}} / \mathrm{M}_{\mathrm{S}}$ as a function of $\mathrm{M}_{\mathrm{S}}$ further demonstrates that less SD-like hysteresis behavior is correlated with a greater abundance of magnetic minerals.

olivine crystal described by Harrison and Lascu (2014) as having magnetite decorations along dislocations. In all of these examples, the peak of the distribution is shifted down toward negative $B_{u}$ values, consistent with a positive mean interaction field (Roberts et al., 2000). Modeling by Harrison and Lascu (2014) suggests that this downward vertical shift arises from interacting clusters with locally anisotropic arrangement of particles, whereas interactions arising from random packing create a negative mean interaction field,

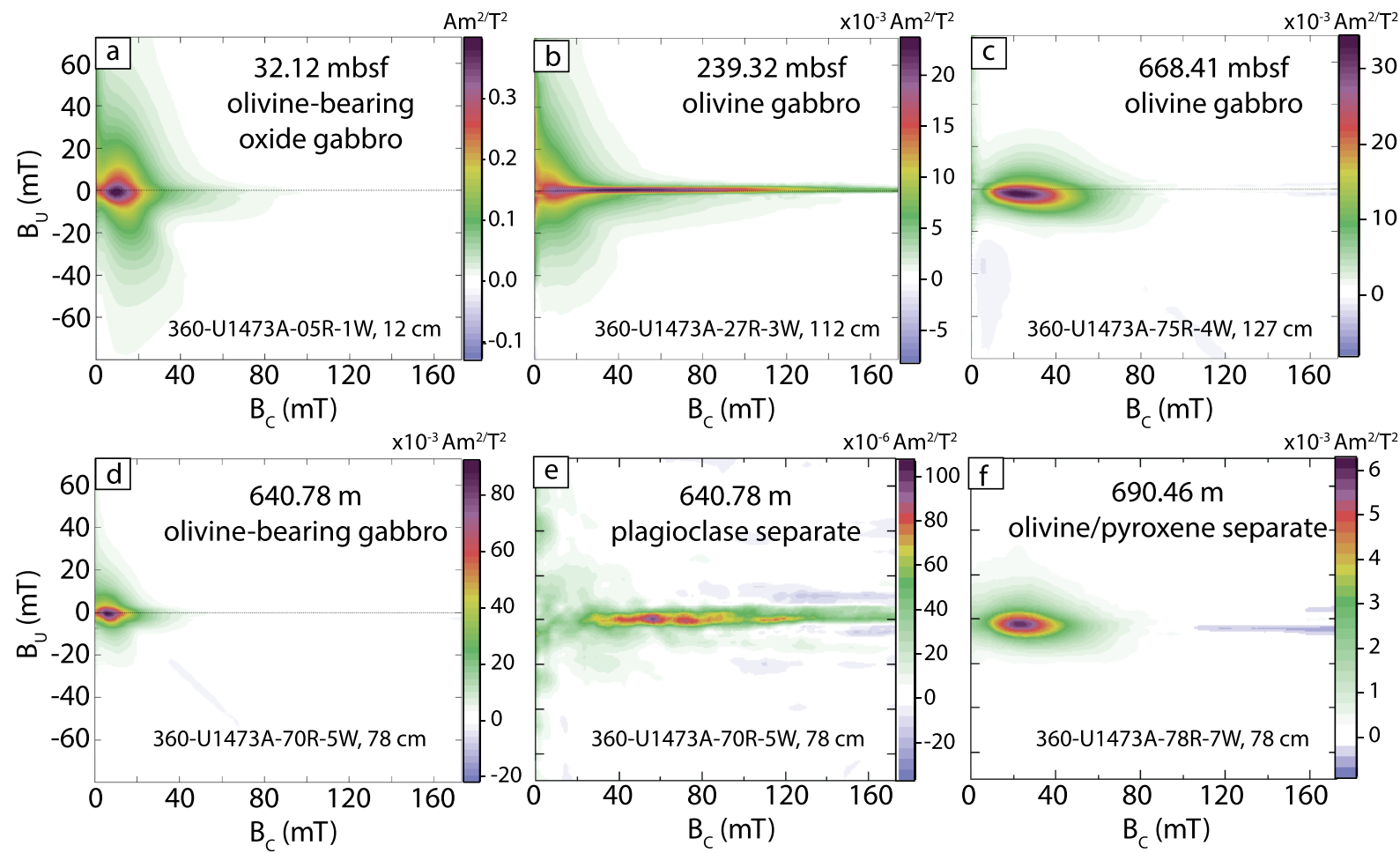

Figure 3. Example FORC results from whole-rock and mineral separates. Results are consistent with at least three endmember populations: (b and e) noninteracting SD, (c and f) interacting SD, and (a and d) "PSD." 

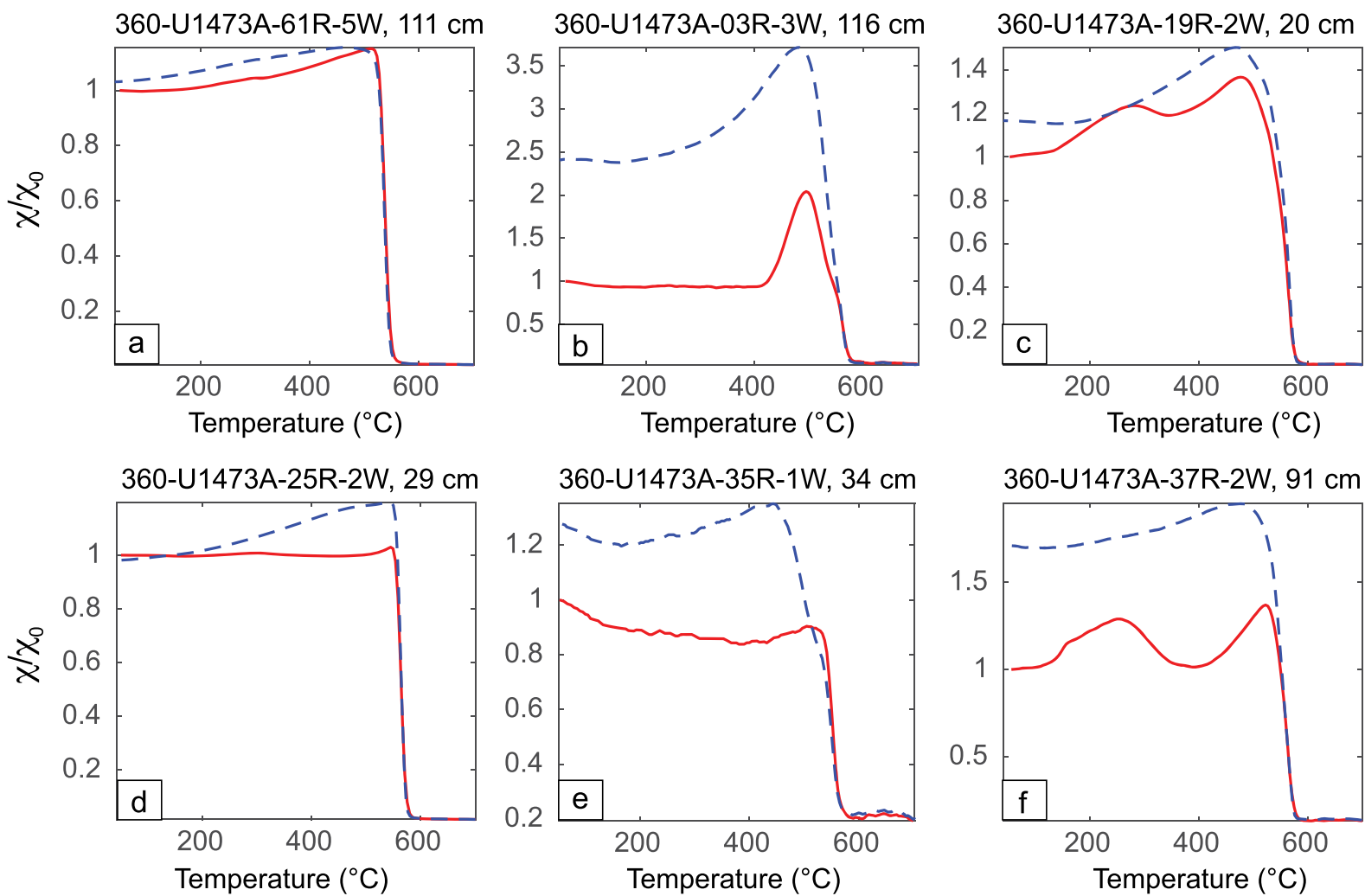

Figure 4. Example thermomagnetic data. Solid red lines measured on warming. Dashed blue lines measured on cooling. "Hump" between $\sim 180$ and $300{ }^{\circ} \mathrm{C}$ (c and f) is associated with hydrothermal alteration at $T \geq 300^{\circ} \mathrm{C}$ (Ade-Hall et al., 1971).

producing an upward shift of the peak in the FORC diagram. Petrographic observations from Atlantis Bank 735B rocks show that magnetite can form along cleavage planes within pyroxene, and along dendritic cracks or crystallographic partings in olivine (Natland, 2002; Pariso \& Johnson, 1993). The observed FORC distribution therefore likely reflects that clustering. We note that the dominant secondary phases at depths $>580 \mathrm{~m}$ CCSF include the products of olivine serpentinization, including magnetite. This depth also approximately correlates with an increase in abundance of this FORC component (see below).

A third component only observed in the bulk rocks has peak coercivities of around 10-15 mT, with increased vertical spread and the development of three "lobes" (Figures 3a, 3b, and 3d). There is some variability in the exact FORC structure (e.g., Figure 3 a versus 3d), and this may actually represent more than one component. This FORC structure is often interpreted as PSD (Lascu et al., 2018; Roberts et al., 2000, 2017), but Harrison and Lascu (2014) point out that there are striking similarities between FORCs measured on samples with grains of "true" PSD size and those measured on strongly interacting SD samples. Samples of fine lamellar magnetite-ulvöspinel intergrowths (Evans et al., 2006) and clusters of biogenically derived SD particles (Miot et al., 2014) both produce FORC diagrams very similar to what we observe in many of the bulk rocks. We suggest that this FORC component arises from clusters of SD-PSD magnetite with small interparticle spacing (Harrison \& Lascu, 2014; perhaps associated with alteration) and/or some type of fine-scale intergrowth in the large oxides (see section 4.5 and Figures 6e and 6f). Rarely do samples show something approaching a true multidomain (MD) signature, with a peak along or very close to the $B_{c}=0$ axis.

FORC principal component analysis shows that $95 \%$ of the variability in the data set is explained by three principal components. Thus, a four-endmember (EM) unmixing was adopted, with EMs that are similar to the components described above: a (mostly) noninteracting SD component (EM1), an interacting single-domain component (EM2), and two different "PSD" components (EM3 and EM4). By selecting physically realistic endmembers that tightly circumscribe the data, a significant number of data points fall outside of the tetrahedron that describes the endmembers (Figure S3). By contrast, if the fit is loosened, more 
360-U1473A-25R-2W, $29 \mathrm{~cm}$
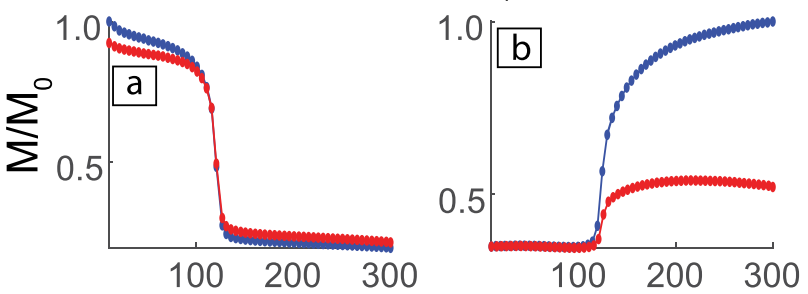

360-U1473A-05R-1W, $12 \mathrm{~cm}$
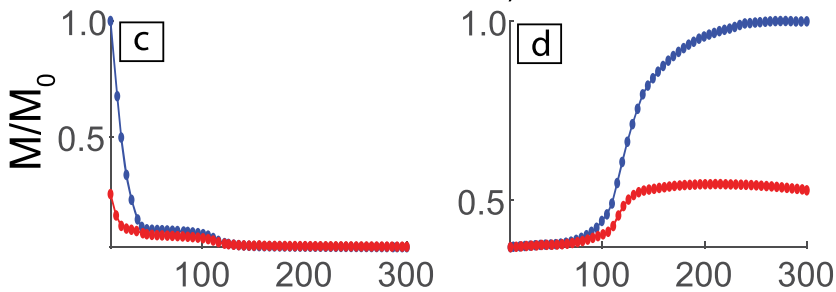

360-U1473A-23R-4W, $28 \mathrm{~cm}$
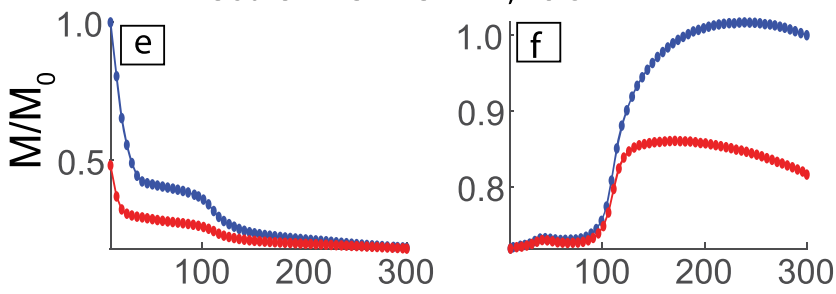

360-U1473A-21R-2W, $116 \mathrm{~cm}$
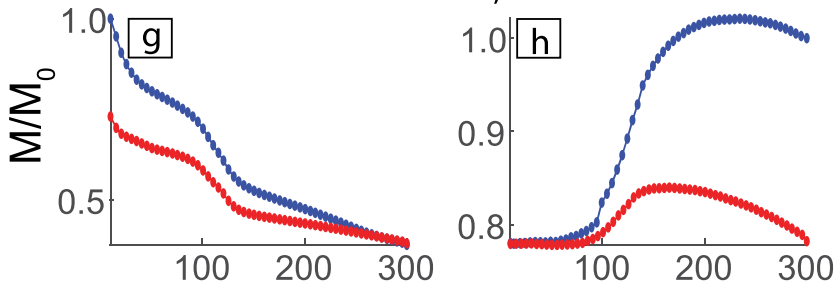

360-U1473A-84R-6W, $101 \mathrm{~cm}$
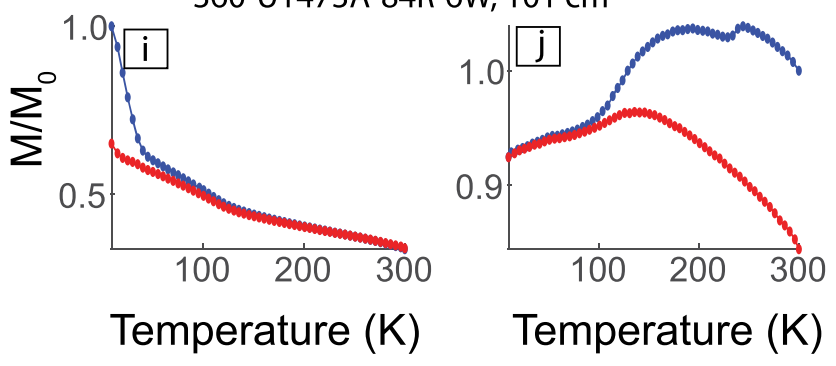

Figure 5. Representative low-temperature remanence data. (left) The 1-T IRM imparted at $10 \mathrm{~K}$ and measured on warming following field-cooling (FC; blue) and zero-field-cooling (ZFC; red). (right) The 1-T IRM imparted at $300 \mathrm{~K}$ and measured on cooling (blue) and warming (red). data fall within the tetrahedron, but with less realistic endmembers. Both sets of endmembers are shown in Figure S3, and the difference between the two (Figure S4) can be taken as an estimate of the uncertainty in the fit. Downhole relative abundance in the average of the two fits is shown in Figure 1d, where the two PSD endmembers are added together for plotting. While imperfect, the analysis provides an estimate of downhole variations in magnetic mineral fractions.

The weakly magnetic, noninteracting SD component is not obvious in many samples, but is more predominant at shallower depths $(<300 \mathrm{~m}$ CCSF). Below $\sim 550 \mathrm{~m} \mathrm{CCSF}$, the interacting SD component becomes more dominant at the expense of the other components (statistically significant increase from $0.11 \pm 0.13$ to $0.32 \pm 0.30$; see also Figure S4). The two SD components are roughly inversely correlated with $M_{s}$, while the PSD components positively correlate with $M_{S}$ (Figure S5). This suggests that the PSD endmembers are linked to the coarse magmatic oxides.

\subsection{Thermomagnetic Data}

All samples have at least one $T_{c}$ close to $560{ }^{\circ} \mathrm{C}$, consistent with low-Ti magnetite (Figure $1 \mathrm{~g}$ and Table S1). The thermomagnetic $\chi(\mathrm{T})$ data display three primary types of behavior, based on the degree of reversibility between the heating and cooling data. Type 1 samples (Figures $4 \mathrm{a}$ and 4d) have mostly reversible behavior, with a final susceptibility very close to the starting value. Type 2 samples (Figures $4 \mathrm{~b}$ and $4 \mathrm{e}$ ) have irreversible behavior, with a significant increase in susceptibility on cooling. Type 3 samples (Figures 4c and 4f) also increase in susceptibility on cooling, but they additionally display a "hump" in the warming curve, between about 180 and $300{ }^{\circ} \mathrm{C}$, that is absent on cooling. Similar behavior has been observed in volcanic rocks and has been linked to hydrothermal alteration (e.g., Ade-Hall et al., 1971; Gee et al., 2010). Type 3 samples are restricted to depths less than $\sim 330 \mathrm{~m}$ CCSF (Figure 1g). More generally, the number of samples with irreversible behavior and the amount of irreversibility also decrease downhole. Irreversibility is quantified as the percent difference in susceptibility at $100{ }^{\circ} \mathrm{C}$ between the warming and cooling curves (Figure 1h).

The three samples with the greatest abundance of magnetic minerals (as measured by $\left.M_{S}>\sim 1.5 \mathrm{Am}^{2} \mathrm{~kg}^{-1}\right)$ have slightly lower $T_{c}\left(\leq \sim 550^{\circ} \mathrm{C}\right)$, while samples with $M_{S}<1.5 \mathrm{Am}^{2} \mathrm{~kg}^{-1}$ almost all have $T_{c}>550{ }^{\circ} \mathrm{C}$, suggesting that some of the coarse magnetite includes additional Ti or other cation impurities. In addition to this primary $550-560{ }^{\circ} \mathrm{C} T_{c}$, seven samples also have a secondary $T_{c}$ (e.g., Figure $4 \mathrm{e}$ ) ranging from $352{ }^{\circ} \mathrm{C}$ to $527{ }^{\circ} \mathrm{C}$ (Figure 1g), consistent with a higher fraction of Ti. All but one of these samples are in the upper $300 \mathrm{~m}$, where concentrations of Fe-Ti oxides are greater. However, there is not a strong correlation between the presence or absence of this secondary $T_{c}$ and either the amount of magnetic material $\left(M_{S}\right)$ or the estimated amount of visible oxides. Finally, data for sample 360-A-U1473-84R-6W, $101 \mathrm{~cm}$ are noisy, but it appears to have an additional inflection near $660-680{ }^{\circ} \mathrm{C}$, consistent with the hematite Néel point.

\subsection{Low-Temperature Data}

All measured samples display a magnetite Verwey transition $\left(T_{v}\right)$ near $120 \mathrm{~K}$ (Table S1) in both the FC/ZFC data and in the 300-K remanence data. In some cases, this signal dominates the low-temperature data, and the $T_{v}$ is quite sharp (Figures $5 \mathrm{a}$ and $5 \mathrm{~b}$ ). In other cases, the transition takes place over a wider temperature 
range (Figures 5d and 5h). In one case, there is only an inflection in the FC/ZFC data (Figure 5i) at $\sim 120 \mathrm{~K}$. The majority of $T_{v}$ values are 121-122 K, but a few are higher (up to $127 \mathrm{~K}$ ) or lower (down to $111 \mathrm{~K}$ ). A suppressed $T_{v}$ may arise from nonstoichiometry and/or cation substitution. For titanomagnetite $\left(\mathrm{Fe}_{3-\mathrm{x}} \mathrm{Ti}_{\mathrm{x}} \mathrm{O}_{4}, 0 \leq\right.$ $\mathrm{x} \leq 1)$, substitution of $0.01 \mathrm{~mol}$ fraction $\mathrm{Ti}(\mathrm{x}=0.01)$ will result in a reduction of $T_{v}$ to about $110 \mathrm{~K}$ (Kozlowski et al., 1996).

The fraction of remanence lost on cooling and warming back through $T_{v}$ increases with an increasing contribution from the FORC PSD endmembers (Figure S6). If the SIRM memory is defined as the ratio of the final remanence at $300 \mathrm{~K}$ divided by the original $\mathrm{SIRM}_{300 \mathrm{~K}}$, memory maximized at about $0.7-0.8$ when the PSD endmembers contribute less than half of the FORC distribution. Memory decreases to about 0.3-0.5 when the PSD endmembers fully dominate the signal. This is consistent with irreversible changes in spin configurations or domain wall movements as would occur in PSD or MD magnetite (Muxworthy \& Williams, 1999).

In seven samples, the $10-\mathrm{K} \mathrm{FC} / \mathrm{ZFC}$ remanence includes a significant component that decays or unblocks at about $\sim 50 \mathrm{~K}$, consistent with an ilmenite fraction (Figures $5 \mathrm{c}$ and $5 \mathrm{e}$ and Table S1). Smaller ilmenite fractions are present in many other samples. The samples with the largest decrease at $\sim 50 \mathrm{~K}$ are more likely to be identified as (olivine-bearing) oxide gabbros (e.g., Figure 5c).

Although subtle, a pyrrhotite Besnus transition (Rochette et al., 1990, 2011) at 27-32 K appears to be present in the 300-K remanence data in at least three samples (Figure $5 \mathrm{f}$ and Table S1). This transition also appears to be present in at least some oceanic gabbros from Atlantis Massif in the Atlantic Ocean (Zhao \& Tominaga, 2009, their Figure 6). Both magmatic and alteration-related sulfides, including pyrrhotite, have been observed in Atlantis Bank gabbros (MacLeod et al., 2017a; Pariso \& Johnson, 1993).

In sample 360-A-U1473-84R-6W, $101 \mathrm{~cm}$, a slight drop in the 300-K remanence on cooling at $\sim 236 \mathrm{~K}$ may be a hematite Morin transition, but there is no corresponding transition in the warming data. The Morin transition is nominally at $262 \mathrm{~K}$ (Morrish, 1994), but small grain size (Özdemir et al., 2008) and/or cation substitution (e.g., Ericsson et al., 1986; Morin, 1950) can lower it. The apparent presence of the hematite Néel point in this same sample (section 4.4) confirms hematite.

In most samples, the FC magnetization is greater than the ZFC magnetization at $T<T_{v}$, but the curves merge at $T>T_{v}$. However, in three samples above $205 \mathrm{~m} \mathrm{CCSF}$, the two curves remain distinct until they reach $300 \mathrm{~K}$. This is consistent with observations of goethite (Liu et al., 2006), which has very high coercivities and a low Néel point ( $~ 395 \mathrm{~K})$, leading to very little isothermal remanent magnetization acquisition at $10 \mathrm{~K}$, but acquisition of a partial thermal remanence during in-field cooling from $300 \mathrm{~K}$.

Although these accessory phases are occasionally present, none of the pyrrhotite, hematite, or goethite appear to carry any significant fraction of NRM, based on the thermal demagnetization data (MacLeod et al., 2017a).

\subsection{Magnetic Force Microscopy Data}

MFM allows us to assess the internal magnetic structure of the coarse oxides. Example MFM results are provided in Figure 6 which shows both sample surface topography (height) along with the magnetic information (phase). Compositional variations are sometimes reflected in the height data because a slight hardness difference affects the polishing effectiveness (e.g., Figure 6f). The phase shift arises when the magnetized tip interacts with stray flux from the sample and produces a shift in the response compared to the driving oscillation of the MFM tip. Dark and light coloring are correlated with flux into or out of the sample surface. Gray represents no vertical flux. A sharp contrast from black to white typically corresponds to domain walls, or grain or compositional boundaries.

MFM results show that the coarse oxides are very rarely multidomain. Rather, they are largely nonmagnetic (Figures 6a-6c) or they have fine-scale exsolution features (Figure 6f) that subdivide the grain into small $(<0.5 \mu \mathrm{m})$, presumably strongly interacting magnetic regions as seen in the small-spatial-scale phase variations in Figure 6e. Pariso and Johnson (1993) described large low-Ti magnetite with fine, elongate ilmenite bodies $<1-2 \mu \mathrm{m}$ in width, larger than what is observed here. The nonmagnetic oxides (e.g., Figure 6a) sometimes have single-domain magnetic inclusions, as seen in Figure $6 \mathrm{~b}$ where two chains of bright/dark spots run from bottom left to top right. 
Reflected light

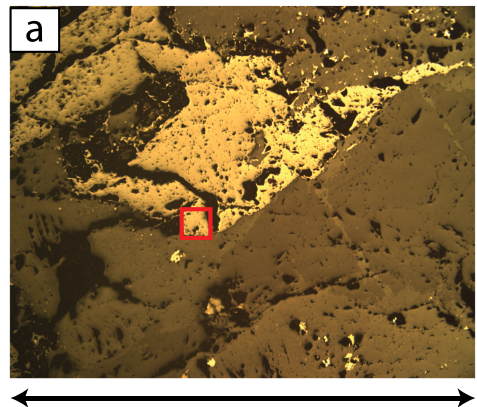

$3.4 \mathrm{~mm}$

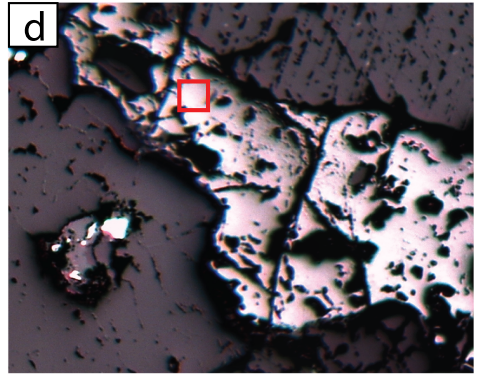

$\sim 1.5 \mathrm{~mm}$

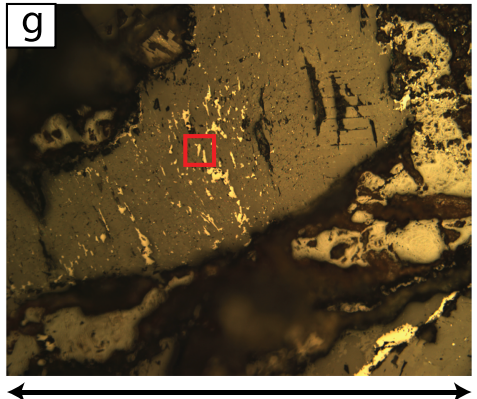

$1.3 \mathrm{~mm}$

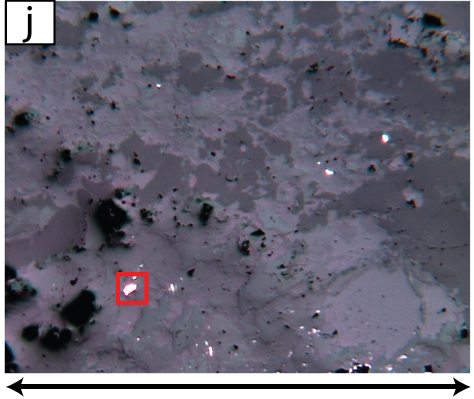

$\sim 1.8 \mathrm{~mm}$
Phase

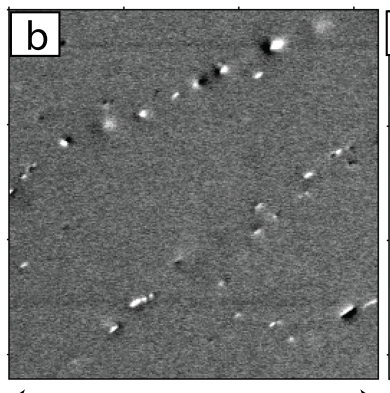

$16 \mu \mathrm{m}$

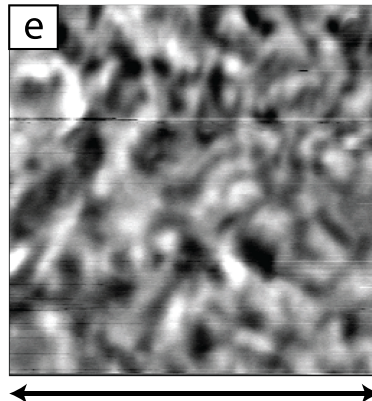

$5.5 \mu \mathrm{m}$

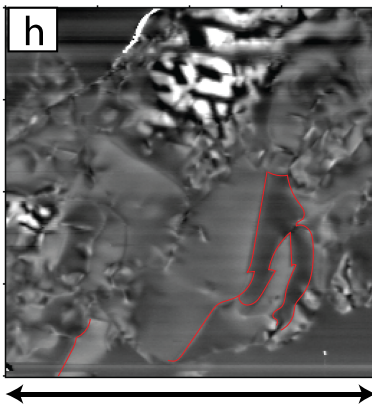

$20 \mu \mathrm{m}$

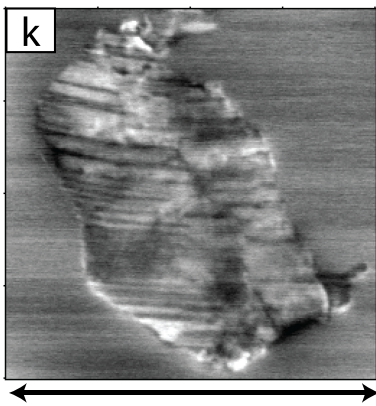

$20 \mu \mathrm{m}$
Height
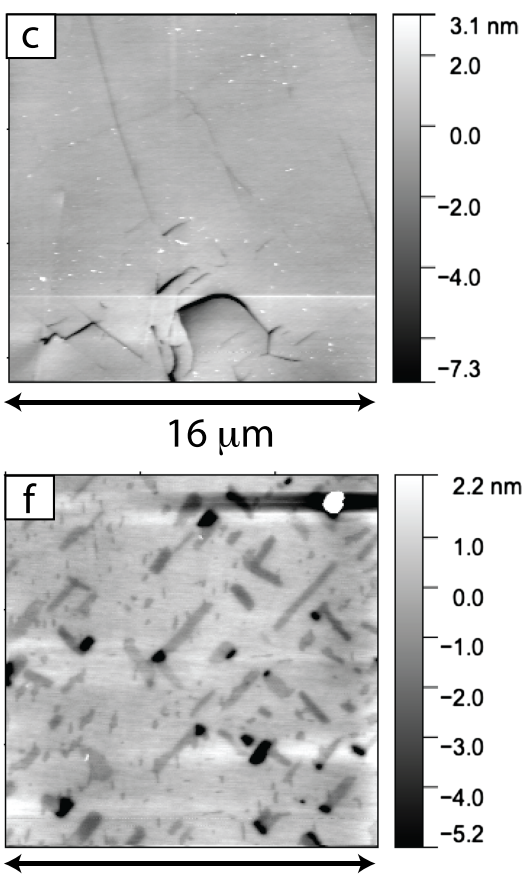

$5.5 \mu \mathrm{m}$
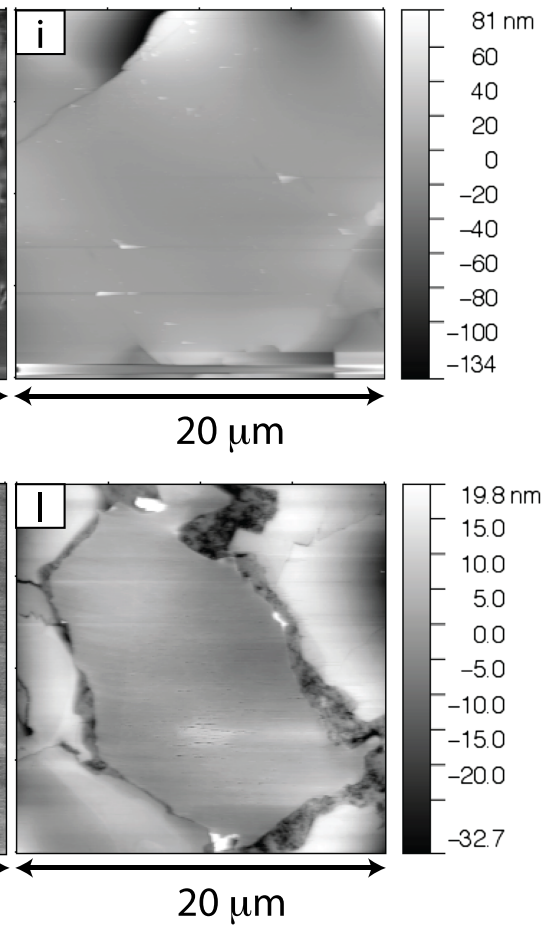

Figure 6. Example magnetic force microscopy (MFM) imagery. (left) Reflected light images. Bright, highly reflective areas are oxides in (a), (d), and (g) and are oxides and sulfides in (j). Red squares show approximate location of MFM images. (middle) Phase data which are related to out-of-plane magnetic flux. Light and dark regions are magnetized in opposite directions. (right) Height image shows topography of area scanned. Scale in nm at right. (a-c) Sample 360-U1473A-5R1-W, 11-13 cm shows an example of a large oxide (a). The ilmenite contains aligned magnetic particles with a single-domain signature (b) that is not reflected in the topography (c). (d-f) Sample 360-U1473A-30R-1-W, 85-89 cm contains a large oxide (d) with fine-scale two-phase exsolution features (e). The compositional variations are reflected in the topography (f). (Large bright spot in top right of $f$ is debris on the sample.) (g-i) Sample 360-U1473A-5R-1-W, 11-13 cm provides an example of a silicate crystal with true multidomain magnetic inclusions. High-contrast domain walls are evident in the top part of the image. Some low-contrast domain walls are highlighted with red lines. (j-1) Sample 360-U1473A-25R-2-W, 28-30 cm (shown at room temperature after heating to $200{ }^{\circ} \mathrm{C}$ ) contains magmatic pyrrhotite with lamellar-like domain structures $(\mathrm{k})$. 
The only observed example of true multidomain behavior was in coarse oxide inclusions in a silicate mineral in sample U1473A-05R-1W, $12 \mathrm{~cm}$ (Figures 6g-6i). Here the domain pattern was typical of that observed in MD magnetite (Pokhil \& Moskowitz, 1997). Complicated domain structures in the top middle part of the image are associated with significant out-of-plane flux and are likely related to surface stresses. The larger, lower contrast regions in the bottom part of the image show more typical domains where flux is mostly inplane. Some of these domain walls unblocked on heating to $200{ }^{\circ} \mathrm{C}$, consistent with MD magnetite (Heider et al., 1988) and/or suggesting that this sample has a moderate amount of Ti substitution. The latter is consistent with the observed secondary $T_{c}$ of $352^{\circ} \mathrm{C}$, corresponding to a titanomagnetite composition of $\mathrm{x} \sim 0.35$.

Sample U1473A-25R-2W, $29 \mathrm{~cm}$ also contained examples of monoclinic pyrrhotite with fine (about $1 \mu \mathrm{m}$ to $<0.5-\mu \mathrm{m}$ width), lamellar domain structures (Figures $6 \mathrm{k}$ and 61 ), typical of this mineral with a strong, basal-plane magnetic anisotropy (e.g., Kontny et al., 2007; Louzada et al., 2010). After heating to $200{ }^{\circ} \mathrm{C}$, the domain walls reorganize into a greater number of domains with less distance between the walls.

\section{Discussion}

At least three forms of magnetite have been identified based on the FORC unmixing: a noninteracting SD component associated with plagioclase, an interacting SD component associated with olivine and/or pyroxene, and one or more PSD components associated with primary magmatic magnetite. There is little variability in the composition of the magnetite, which has a consistent Curie temperature throughout the hole, regardless of the dominant magnetite population. Although the reported Curie temperatures are close to $560{ }^{\circ} \mathrm{C}$, this is likely an underestimate due to calibration issues with the temperature sensor. The presence of Verwey transition temperatures near $120 \mathrm{~K}$ suggests that the magnetite must be very close to stoichiometric, with few impurities. Pariso and Johnson (1993) report an average $T_{c}$ of $582{ }^{\circ} \mathrm{C}$ from the Leg 118 Atlantis Bank samples from Hole 735B, and we believe that our data are consistent with this. A few samples do have secondary, lower $T_{c} \mathrm{~s}$, consistent with the incorporation of some Ti or other impurity.

The thermomagnetic data also demonstrate that the uppermost $\sim 500 \mathrm{~m}$ has undergone some kind of hydrothermal alteration. The hump in the $\chi(\mathrm{T})$ warming curves has been linked specifically to hydrothermal alteration at $>\sim 300{ }^{\circ} \mathrm{C}$ (Ade-Hall et al., 1971). The overall irreversibility in the thermomagnetic data may arise from the presence of clays that then undergo alteration during the $\chi(\mathrm{T})$ measurements, forming magnetite on heating. The magnetic signature of goethite is consistent with observations of clays and other geochemical and mineralogical observations demonstrating that the uppermost few hundred meters of Atlantis Bank has undergone high-grade granulite to amphibole facies alteration (Barnes \& Cisneros, 2012; Cheadle et al., 2016; Kendrick, 2019; MacLeod et al., 2017a).

As mentioned above (section 2.1), there is clearly a link between the shipboard-defined lithology and magnetization intensity that is associated with the abundance of primary magmatic oxides. It is important now to distinguish between these discrete lithological units, which reflect approximate average variations in mineral abundance (including oxides), and the continuous variations in $M_{s}$ and other magnetic properties that likely reflect real heterogeneity in oxide abundance at smaller spatial scales. In the following, we assume that $M_{S}$ more accurately reflects the abundance of magnetic oxides.

The magnetic data present a cohesive picture of a downhole decrease in average magnetic grain size that also correlates with a decrease in average magnetization intensity and inferred oxide abundance. This transition happens between about 400 and $600 \mathrm{~m} \mathrm{CCSF}$, and below this depth MDF, median destructive temperature, and $M_{\mathrm{rs}} / M_{S}$ are higher (Figure 1), all consistent with a smaller average grain size. On average, there is an increase in the SD FORC endmembers and a decrease in the PSD FORC endmembers at depth. The more common acquisition of a gyroremanent magnetization in the lower part of the hole is also consistent with a SD mineralogy. Although variations derived from NRM (including MDF) could be influenced by a drilling overprint, this is not true for high-field measurements (hysteresis, FORC).

Magnetic domain state is also linked to magnetization intensity. The lower coercivity, PSD behavior tends to be associated with higher NRM and $M_{S}$ (Figures 1, 2, and S3). This strongly suggests that the PSD behavior is associated with the coarse, volumetrically abundant, primary magmatic oxides found (on average) in higher concentrations in the oxide- and oxide-bearing (olivine) gabbros. When present in great enough abundance, the coarse oxides likely mask the presence of the remaining signal which comes dominantly from 
finer-grained magnetite inclusions in olivine and/or pyroxene, with some contributions from plagioclase. Some of the noninteracting SD signal may also come from the exsolution of SD magnetite within ilmenite or other nonmagnetic oxides (e.g., Figures 6a-6c).

In spite of their large size (up to several millimeters), the coarse, magmatic oxides do not show multidomain behavior, but have FORC distributions consistent with PSD and/or strongly interacting single-domain particles. MFM imaging demonstrates that this behavior arises from very fine lamellar exsolution featureslikely either magnetite-ulvöspinel or magnetite-ilmenite. The intergrowths serve to subdivide the larger grains into regions $<0.5 \mu \mathrm{m}$. This may include regions of true SD size, but certainly includes larger regions that have traditionally been termed "pseudo-single-domain." In fact, these PSD-size particles or regions represent a complex range of behaviors associated with vortex states (e.g., Lascu et al., 2018; Roberts et al., 2017). Here the behavior of the regions will be additionally complicated by strong interactions. While these samples have lower coercivity than samples lacking coarse oxides, they will be more stable over geologic time compared to true multidomain magnetite.

The coarse oxides will contribute more strongly to near-bottom magnetic anomalies because the oxide-rich gabbros are closer to the seafloor and have an NRM at least 1 order of magnitude higher than regular olivine gabbros ( 0.45 versus $2.11 \mathrm{~A} \mathrm{~m}^{-1}$; section 2.1). Although the abundance of magnetic oxides is clearly gradational and heterogeneous on small spatial scales, at a larger scale we may characterize the source layer as a two endmember system. One endmember is dominated by strongly magnetic oxide-rich gabbros with a greater PSD contribution and the other by more weakly magnetic regular gabbros with more SD-like behavior. As demonstrated by geological mapping and drilling elsewhere on Atlantis Bank, the distribution of oxide-rich gabbros is laterally heterogeneous and may lead to strong intensity contrasts that could complicate anomaly interpretations. Further complications will arise if magnetization acquisition is asynchronous across these two components, leading to a shift in polarity boundaries. This could happen if the coarse oxides are magnetically viscous and carry a significant normal overprint. However, they appear to carry a relatively stable remanence of reverse polarity, identical to the polarity of the less magnetic gabbros and consistent with cooling during reverse Chron C5r.3r (MacLeod et al., 2017a). Therefore, assuming that all magnetite was formed at $T>T_{c}$ and the two units were thermally homogeneous as they cooled, there should be no discontinuity in the polarity boundary related to lithology.

\section{Acknowledgments}

This work used samples and data provided by the International Ocean Discovery Program. Funding was provided by the U.S. Science Support Program (J.B.). I.L. has benefited from a Smithsonian Edward and Helen Hintz Secretarial Scholarship. We thank the members of the IODP Expedition 360 Science Party, and the captain and crew of the JOIDES Resolution. Part of this work was done as a Visiting Fellow at the Institute for Rock Magnetism (IRM) at the University of Minnesota. The IRM is made possible through the Instrumentation and Facilities program of the National Science Foundation,

Earth Sciences Division, and by funding from the University of Minnesota. We would like to thank IRM staff M. Jackson, P. Solheid, and D. Bilardello for their generous assistance. Many thanks to A. Butula, K. Vernon, and J. Marquardt for their assistance with rock magnetic measurements at UWM and to L. McHenry for assistance with XRD. We also thank two anonymous reviewers for their thoughtful comments that improved the manuscript. Magnetic data associated with this manuscript are available in the Magnetics Information Consortium (MagIC) database at https://www. earthref.org/MagIC/doi/10.1029/ 2019GC008847. XRD data are available at https://zenodo.org/record/3611642.

\section{Conclusions}

Gabbro samples from International Ocean Discovery Program Hole U1473A on Atlantis Bank near the Southwest Indian Ridge have magnetic remanence and magnetic properties that are dominated by mostly pure magnetite, present in at least three forms. In the uppermost $400-600 \mathrm{~m}$ of the hole, coarse (up to several millimeters) primary magmatic oxides with fine-scale intergrowths dominate the signal. These are most abundant in the Fe-Ti oxide gabbros found more frequently in the uppermost parts of the hole. Additional contributions are from magnetic inclusions in plagioclase, olivine, and/or pyroxene. The magnetic signature of the coarse oxides is similar to that of PSD magnetite, arising from strongly interacting magnetic regions of $<0.5 \mu \mathrm{m}$ in size, resulting from the intergrowths. Plagioclase inclusions have a noninteracting SD signature, and this component rarely dominates the bulk rock signature. The olivine and/or pyroxene inclusions have an interacting SD signature, likely arising from clusters of magnetite along crystal discontinuities, such as fractures or cleavage planes. This interacting SD component becomes more prominant at depths $>600 \mathrm{~m}$ CCSF. At Atlantis Bank, the magnetic contribution from the coarse oxides which are volumetrically abundant in the near-surface oxide gabbros will likely dominate the near-bottom magnetic anomaly signal.

\section{References}

Ade-Hall, J. M., Palmer, H. C., \& Hubbard, T. P. (1971). The magnetic and opaque petrological response of basalts to regional hydrothermal alteration. Geophysical Journal International, 24, 137-174.

Allerton, S., \& Tivey, M. (2001). Magnetic polarity structure of the lower crust. Geophysical Research Letters, 28, 423-426.

Arkani-Hamed, J. (1990). Magnetization of the oceanic crust beneath the Labrador Sea. Journal of Geophysical Research, 95, 7101-7110.

Barnes, J. D., \& Cisneros, M. (2012). Mineralogical control on the chlorine isotope composition of altered oceanic crust. Chemical Geology, $326,51-60$.

Bowers, N. E., Cande, S. C., Gee, J. S., Hildebrand, J. A., \& Parker, R. L. (2001). Fluctuations of the paleomagnetic field during chron C5 as recorded in near-bottom marine magnetic anomaly data. Journal of Geophysical Research, 106, 26,379-26,396. 
Cande, S. C., \& Kent, D. V. (1976). Constraints imposed by the shape of marine magnetic anomalies on the magnetic source. Journal of Geophysical Research, 81, 4157-4162.

Cande, S. C., \& Kent, D. V. (1995). Revised calibration of the geomagnetic polarity timescale for the Late Cretaceous and Cenozoic. Journal of Geophysical Research, 100, 6093-6095.

Caratori Tontini, F., Crone, T. J., de Ronde, C. E. J., Fornari, D. J., Kinsey, J. C., Mittelstaedt, E., \& Tivey, M. (2016). Crustal magnetization and the subseafloor structure of the ASHES vent field, Axial Seamount, Juan de Fuca Ridge: Implications for the investigation of hydrothermal sites. Geophysical Research Letters, 43, 6205-6211. https://doi.org/10.1002/2016GL069430

Cheadle, M. J., John, B. E., Coble, M. A., Koepke, J., Rioux, M. E., Liu, C. Z., \& Expedition 360 Scientists (2016). The age of IODP Site 1473, Atlantis Bank: Constraints from initial zircon U-Pb dating and geochemistry by SIMS, paper presented at AGU Fall Meeting, San Francisco, CA, abstract \#OS31D-2052.

Davis, K. E. (1981). Magnetite rods in plagioclase as the primary carrier of stable NRM in ocean floor gabbros. Earth and Planetary Science Letters, 55, 190-198.

Day, R., Fuller, M., \& Schmidt, V. A. (1977). Hysteresis properties of titanomagnetites: Grain-size and compositional dependence. Physics of the Earth and Planetary Interiors, 13, 260-267.

Dick, H. J. B., Kvassnes, A. J. S., Robinson, P. T., MacLeod, C. J., \& Kinoshita, H. (2019). The Atlantis Bank Gabbro Massif, Southwest Indian Ridge. Progress in Earth and Planetary Science, 6(1), 1-70. https://doi.org/10.1186/s40645-019-0307-9

Dick, H. J. B., MacLeod, C. J., Blum, P., Abe, N., Blackman, D. K., Bowles, J. A., et al. (2019). Dynamic accretion beneath a slow-spreading ridge segment: IODP Hole 1473A and the Atlantis Bank Oceanic Core Complex. Journal of Geophysical Research: Solid Earth, 124, 12,631-12,659. https://doi.org/10.1029/2018JB016858

Dick, H. J. B., Natland, J. H., Alt, J. C., Bach, W., Bideau, D., Gee, J. S., et al. (2000). A long in situ section of the lower ocean crust: Results of ODP Leg 176 drilling at the Southwest Indian Ridge. Earth and Planetary Science Letters, 179, 31-51.

Dick, H. J. B., Schouten, H., Meyer, P. S., Gallo, D. G., Bergh, H., Tyce, R., et al. (1991). Tectonic evolution of the Atlantis II Fracture Zone. In R. P. Von Herzen, P. T. Robinson, et al. (Eds.), Proc. ODP, Sci. Results (Vol. 118, pp. 359-398). College Station, TX: Ocean Drilling Program.

Dunlop, D. J. (2002). Theory and application of the Day plot $\left(\mathrm{M}_{\mathrm{rs}} / \mathrm{M}_{\mathrm{s}}\right.$ versus $\left.\mathrm{H}_{\mathrm{cr}} / \mathrm{H}_{\mathrm{c}}\right)$ : 1 . Theoretical curves and tests using titanomagnetite data. Journal of Geophysical Research, 107(B3), 2056. https://doi.org/10.1029/2001JB000486

Dyment, J., Cande, S. C., \& Arkani-Hamed, J. (1994). Skewness of marine magnetic anomalies created between 85 and 40 Ma in the Indian Ocean. Journal of Geophysical Research, 99, 24,121-24,134.

Egli, R. (2013). VARIFORC: An optimized protocol for calculating non-regular first-order reversal curve (FORC) diagrams. Global and Planetary Change, 110, 302-320.

Ericsson, T., Krisnhamurthy, A., \& Srivastava, B. K. (1986). Morin-transition in Ti-substituted hematite: A Mössbauer study. Physica Scripta, 33, 88-90.

Evans, M. E., Krása, D., Williams, W., \& Winklhofer, M. (2006). Magnetostatic interactions in a natural magnetite-ulvöspinel system. Journal of Geophysical Research, 111, B12S16. https://doi.org/10.1029/2006JB004454

Expedition 304/305 Scientists (2006). Site U1309. In D. K. Blackman, B. Ildefonse, B. E. John, Y. Ohara, D. J. Miller, C. J. MacLeod, \& Expedition 304/305 Scientists (Eds), Proc. IODP (Vol. 304/305, pp. 1-509). College Station, TX: Integrated Ocean Drilling Program.

Garcés, M., \& Gee, J. S. (2007). Paleomagnetic evidence of large footwall rotations associated with low-angle faults at the Mid-Atlantic Ridge. Geology, 35, 279-282.

Gee, J. S., Cande, S. C., Hildebrand, J. A., Donnelly, K., \& Parker, R. L. (2000). Geomagnetic intensity variations over the past 780 kyr obtained from near-seafloor magnetic anomalies. Nature, 408(6814), 827-832. https://doi.org/10.1038/35048513

Gee, J. S., \& Kent, D. V. (2007). Source of oceanic magnetic anomalies and the geomagnetic polarity timescale. In M. Kono (Ed.), Treatise on Geophysics (Vol. 5, pp. 455-507). Amsterdam, Netherlands: Elsevier.

Gee, J. S., Lawrence, R. M., \& Hurst, S. D. (1997). Remanence characteristics of gabbros from the Mark area: Implications for crustal magnetization. In J. A. Karson, M. Cannat, D. J. Miller, \& D. Elthon (Eds.), Proc. ODP, Sci. Results (Vol. 153, pp. 429-436). College Station, TX: Ocean Drilling Program.

Gee, J. S., \& Meurer, W. P. (2002). Slow cooling of middle and lower oceanic crust inferred from multicomponent magnetizations of gabbroic rocks from the Mid-Atlantic Ridge south of the Kane fracture zone (MARK) area. Journal of Geophysical Research, 107(B7), 2137. https://doi.org/10.1029/2000JB000062

Gee, J. S., Yu, Y., \& Bowles, J. (2010). Paleointensity estimates from ignimbrites: An evaluation of the Bishop Tuff. Geochemistry, Geophysics, Geosystems, 11, Q03010. https://doi.org/10.1029/2009GC002834

Granot, R., Dyment, J., \& Gallet, Y. (2012). Geomagnetic field variability during the Cretaceous Normal Superchron. Nature Geoscience, 5, 220.

Harrison, R. J., \& Feinberg, J. M. (2008). FORCinel: An improved algorithm for calculating first-order reversal curve distributions using locally weighted regression smoothing. Geochemistry, Geophysics, Geosystems, 9, Q05016. https://doi.org/10.1029/ $2008 \mathrm{GC} 001987$

Harrison, R. J., \& Lascu, I. (2014). FORCulator: A micromagnetic tool for simulating first-order reversal curve diagrams. Geochemistry, Geophysics, Geosystems, 15(12), 4671-4691. https://doi.org/10.1002/2014GC005582

Harrison, R. J., Muraszko, J., Heslop, D., Lascu, I., Muxworthy, A. R., \& Roberts, A. P. (2018). An improved algorithm for unmixing first-order reversal curve diagrams using principal component analysis. Geochemistry, Geophysics, Geosystems, 19(5), 1595-1610. https:// doi.org/10.1029/2018GC007511

Heider, F., Halgedahl, S. L., \& Dunlop, D. J. (1988). Temperature dependence of magnetic domains in magnetite crystals. Geophysical Research Letters, 15, 499-502.

Heirtzler, J. R., Dickson, G. O., Herron, E. M., Pitman, W. C. III, \& LePichon, X. (1968). Marine magnetic anomalies, geomagnetic field reversals, and motions of the ocean floor and continents. Journal of Geophysical Research, 73, 2119-2136.

Kelemen, P. B., Kikawa, E., Miller, D. J., \& ODP Leg 209 Scientific Party (Eds.) (2004). Proc. ODP, Init. Repts (Vol. 209). College Station, TX: Ocean Drilling Program.

Kendrick, M. A. (2019). Halogens in Atlantis Bank gabbros, SW Indian Ridge: Implications for styles of seafloor alteration. Earth and Planetary Science Letters, 514, 96-107.

Kikawa, E., \& Pariso, J. E. (1991). Magnetic properties of gabbros from Hole 735B, Southwest Indian Ridge. In R. P. Von Herzen, P. T. Robinson, et al. (Eds.), Proc. ODP, Sci. Results (Vol. 118, pp. 285-307). College Station, TX: Ocean Drilling Program.

Kontny, A., Elbra, T., Just, J., Pesonen, L. J., Schleicher, A. M., \& Zolk, J. (2007). Petrography and shock-related remagnetization of pyrrhotite in drill cores from the Bosumtwi Impact Crater Drilling Project, Ghana. Meteoritics \& Planetary Science, 42, 811-827. 
Kozlowski, A., Kakol, Z., Kim, D., Zalecki, R., \& Honig, J. M. (1996). Heat capacity of $\mathrm{Fe}_{3-\mathrm{a}} \mathrm{M}_{\mathrm{a}} \mathrm{O}_{4}(\mathrm{M}=\mathrm{Zn}, \mathrm{Ti}, 0<=\mathrm{a}<=0.04)$. Physical Review $B, 54,12,093-12,098$.

Lascu, I., Einsle, J. F., Ball, M. R., \& Harrison, R. J. (2018). The vortex state in geologic materials: A micromagnetic perspective. Journal of Geophysical Research: Solid Earth, 123, 7285-7304. https://doi.org/10.1029/2018JB015909

Lascu, I., Harrison, R. J., Li, Y., Muraszko, J. R., Channell, J. E. T., Piotrowski, A. M., \& Hodell, D. A. (2015). Magnetic unmixing of first-order reversal curve diagrams using principal component analysis. Geochemistry, Geophysics, Geosystems, 16(9), 2900-2915. https:// doi.org/10.1002/2015GC005909

Liu, Q., Yu, Y., Torrent, J., Roberts, A. P., Pan, Y., \& Zhu, R. (2006). Characteristic low-temperature magnetic properties of aluminous goethite $[\alpha-(\mathrm{Fe}, \mathrm{Al}) \mathrm{OOH}]$ explained. Journal of Geophysical Research, 111, B12S34. https://doi.org/10.1029/2006JB004560

Louzada, K. L., Stewart, S. T., Weiss, B. P., Gattacceca, J., \& Bezaeva, N. S. (2010). Shock and static pressure demagnetization of pyrrhotite and implications for the Martian crust. Earth and Planetary Science Letters, 290, 90-101.

Macdonald, K. C., Miller, S. P., Luyendyk, B. P., Atwater, T. M., \& Shure, L. (1983). Investigation of a Vine-Matthews magnetic lineation from a submersible: The source and character of marine magnetic anomalies. Journal of Geophysical Research, 88, 3403-3418.

MacLeod, C. J., Dick, H., Blum, P., \& Expedition 360 Scientists (2017a). Site U1473. In C. J. MacLeod, H. J. B. Dick, P. Blum, \& Expedition 360 Scientists (Eds.), Proceedings of the International Ocean Discovery Program (Vol. 360, pp. 1-136). College Station, TX: International Ocean Discovery Program.

MacLeod, C. J., Dick, H. J. B., Blum, P., \& Expedition 360 Scientists (2017b). Southwest Indian Ridge lower crust and Moho. In Proceedings of the International Ocean Discovery Program (Vol. 360, pp. 1-136). College Station, TX: International Ocean Discovery Program.

Miot, J., Li, J., Benzerara, K., Sougrati, M. T., Ona-Nguema, G., Bernard, S., et al. (2014). Formation of single domain magnetite by green rust oxidation promoted by microbial anaerobic nitrate-dependent iron oxidation. Geochimica et Cosmochimica Acta, 139, 327-343.

Morin, F. J. (1950). Magnetic susceptibility of $\mathrm{aFe}_{2} \mathrm{O}_{3}$ and $\mathrm{aFe}_{2} \mathrm{O}_{3}$ with added titanium. Physics Review, 78, 819-820.

Morris, A., Gee, J. S., Pressling, N., John, B. E., MacLeod, C. J., Grimes, C. B., \& Searle, R. C. (2009). Footwall rotation in an oceanic core complex quantified using reoriented Integrated Ocean Drilling Program core samples. Earth and Planetary Science Letters, 287, 217-228. https://doi.org/10.1016/j.epsl.2009.08.007

Morrish, A. H. (1994). Canted antiferromagnetism: Hematite (p. 192). River Edge, NJ: World Scientific.

Muxworthy, A. R., \& Williams, W. (1999). Micromagnetic models of pseudo-single domain grains of magnetite near the Verwey transition. Journal of Geophysical Research, 104, 29,203-29,217.

Natland, J. H. (2002). Magnetic susceptibility as an index of the lithology and composition of gabbros, ODP Leg 176, Hole 735B, Southwest Indian Ridge. In J. H. Natland, H. J. B. Dick, D. J. Miller, \& R. P. Von Herzen (Eds.), Proceedings of the Ocean Drilling Program, Scientific Results (Vol. 176, pp. 1-69). College Station, TX: Ocean Drilling Program.

Natland, J. H., \& Dick, H. J. B. (2001). Formation of the lower ocean crust and the crystallization of gabbroic cumulates at a very slowly spreading ridge. Journal of Volcanology and Geothermal Research, 110, 191-233.

Özdemir, Ö., Dunlop, D., \& Berquo, T. S. (2008). Morin transition in hematite: Size dependence and thermal hysteresis. Geochemistry, Geophysics, Geosystems, 9, Q10Z01. https://doi.org/10.1029/2008GC002110

Pariso, J. E., \& Johnson, H. P. (1993). Do lower crustal rocks record reversals of the Earth's magnetic field? Magnetic petrology of oceanic gabbros from Ocean Drilling Program Hole 735B. Journal of Geophysical Research, 98, 16,063-16,032.

Pariso, J. E., Kelso, P., \& Richter, C. (1996). Paleomagnetism and rock magnetic properties of gabbro from Hole 894G, Hess Deep. In C. Mevel, K. M. Gillis, J. F. Allan, \& P. S. Meyer (Eds.), Proc. ODP, Sci. Results (Vol. 147, pp. 373-381). College Station, TX: Ocean Drilling Program.

Petrovský, E., \& Kapička, A. (2006). On determination of the Curie point from thermomagnetic curves. Journal of Geophysical Research, 111, B12S27. https://doi.org/10.1029/2006JB004507

Pitman, W. C., \& Heirtzler, J. R. (1966). Magnetic anomalies over the Pacific-Antarctic ridge. Science, 154(3753), 1164-1171. https://doi.org/ 10.1126/science.154.3753.1164

Pokhil, T. G., \& Moskowitz, B. M. (1997). Magnetic domains and domain walls in pseudo-single-domain magnetite studied with magnetic force microscopy. Journal of Geophysical Research, 102, 22,681-22,694.

Rao, D. G., \& Krishna, K. S. (2002). Magnetic rock properties of the gabbros from the ODP Drill Hole 1105A of the Atlantis Bank, Southwest Indian Ridge. Proceedings of the Indian Academy of Sciences, 111, 467-481.

Roberts, A. P., Almeida, T. P., Church, N. S., Harrison, R. J., Heslop, D., Li, Y., et al. (2017). Resolving the origin of pseudo-single domain magnetic behavior. Journal of Geophysical Research: Solid Earth, 122, 9534-9558. https://doi.org/10.1002/2017JB014860

Roberts, A. P., Pike, C. R., \& Verosub, K. L. (2000). First-order reversal curve diagrams: A new tool for characterizing the magnetic properties of natural samples. Journal of Geophysical Research, 105, 28,461-28,475.

Rochette, P., Fillion, G., \& Dekkers, M. J. (2011). Interpretation of low-temperature data part 4: The low-temperature magnetic transition of monoclinic pyrrhotite. IRM Quarterly, 21, 1-11.

Rochette, P., Fillion, G., Mattei, J. L., \& Dekkers, M. J. (1990). Magnetic transition at 30-34 K in pyrrhotite: Insight into a widespread occurrence of this mineral in rocks. Earth and Planetary Science Letters, 98, 319-328.

Sager, W. W., Weiss, C. J., Tivey, M. A., \& Johnson, H. P. (1998). Geomagnetic polarity reversal model of deep-tow profiles from the Pacific Jurassic Quiet Zone. Journal of Geophysical Research, 103, 5269-5286.

Schouten, H., \& Cande, S. C. (1976). Palaeomagnetic poles from marine magnetic anomalies. Geophysical Journal of the Royal Astronomical Society, 44, 567-575.

Schouten, H., \& Denham, C. R. (1979). Modeling the oceanic magnetic source layer. In M. Talwani, C. G. Harrison, \& D. E. Hayes (Eds.), Deep Drilling Results in the Atlantic Ocean: Ocean Crust (Vol. 2, pp. 151-159). Washington, DC: American Geophysical Union.

Schulz, N. J., Detrick, R. S., \& Miller, S. P. (1988). Two-and three-dimensional inversions of magnetic anomalies in the MARK area (MidAtlantic Ridge $\left.23^{\circ} \mathrm{N}\right)$. Marine Geophysical Researches, 10, 41-57.

Shipboard Scientific Party (1989). Hole 735B. In P. T. Robinson, R. P. Von Herzen, et al. (Eds.), Proc. ODP, Init. Repts (Vol. 118, pp. 89-222). College Station, TX: Ocean Drilling Program.

Shipboard Scientific Party (1999). Site 735. In H. J. B. Dick, J. H. Natland, D. J. Miller, et al. (Eds.), Proc. ODP, Init. Repts. (Vol. 176, pp. 1-314). College Station, TX: Ocean Drilling Program.

Stephenson, A. (1993). Three-axis static alternating field demagnetization of rocks and the identification of natural remanent magnetization, gyroremanent magnetization, and anisotropy. Journal of Geophysical Research, 98, 373-381.

Tivey, M. A., \& Johnson, H. P. (2002). Crustal magnetization reveals subsurface structure of Juan de Fuca Ridge hydrothermal vent fields Geology, 30, 979-982. 
Tivey, M. A., Johnson, H. P., Fleutelot, C., Hussenoeder, S., Lawrence, R., Waters, C., \& Wooding, B. (1998). Direct measurement of magnetic reversal polarity boundaries in a cross-section of oceanic crust. Geophysical Research Letters, 25, 3631-3634.

Tivey, M. A., Sager, W. W., Lee, S.-M., \& Tominaga, M. (2006). Origin of the Pacific Jurassic quiet zone. Geology, 34, 789-792.

Tivey, M. A., Schouten, H., \& Kleinrock, M. C. (2003). A near-bottom magnetic survey of the Mid-Atlantic Ridge axis at $26^{\circ}$ N: Implications for the tectonic evolution of the TAG segment. Journal of Geophysical Research, 108(B5), 2277. https://doi.org/10.1029/2002JB001967

Tivey, M. A., \& Tucholke, B. E. (1998). Magnetization of 0-29 Ma ocean crust on the Mid-Atlantic Ridge, $25^{\circ} 30^{\prime}$ to $27^{\circ} 10^{\prime} \mathrm{N}$. Journal of Geophysical Research, 103, 17,807-17,826.

Tominaga, M., Sager, W. W., Tivey, M. A., \& Lee, S.-M. (2008). Deep-tow magnetic anomaly study of the Pacific Jurassic Quiet Zone and implications for the geomagnetic polarity reversal timescale and geomagnetic field behavior. Journal of Geophysical Research, 113, B07110. https://doi.org/10.1029/2007JB005527

Usui, Y. (2013). Paleointensity estimates from oceanic gabbros: Effects of hydrothermal alteration and cooling rate. Earth, Planets and Space, 65, 985-996.

Vine, F. J., \& Matthews, D. H. (1963). Magnetic anomalies over oceanic ridges. Nature, 199, 947-949.

Zhao, X., \& Tominaga, M. (2009). Paleomagnetic and rock magnetic results from lower crustal rocks of IODP Site U1309: Implication for thermal and accretion history of the Atlantis Massif. Tectonophysics, 474, 435-448. 